\title{
Cauda equine syndrome as the primary symptom of leptomeningeal metastases from lung cancer: a case report and review of literature
}

This article was published in the following Dove Press journal:

OncoTargets and Therapy

\author{
Yang Liu* \\ Bin Wang* \\ Yongxiang Qian \\ Dongmei Di \\ Min Wang \\ Xiaoying Zhang \\ Department of Cardiothoracic \\ Surgery, The Third Affiliated Hospital \\ of Soochow University, Changzhou \\ 213003, China \\ *These authors contributed equally \\ to this work
}

Correspondence: Xiaoying Zhang Department of Cardiothoracic Surgery, The Third Affiliated Hospital of Soochow University, I 85 Juqian Street, Changzhou 213003, China

Tel +86 I39 6III59966

Email zhangxy6689996@163.com

\begin{abstract}
Cauda equine syndrome (CES) is a neurological condition caused by compression of the cauda equine. Here, we demonstrate a case of CES as the primary symptom of leptomeningeal metastases from non-small cell lung carcinoma without brain metastases. A 59-year-old male suffered progressive lower extremity motor dysfunction, urinary dysfunction, and lower extremity sensory dysfunction. He was clinically diagnosed with CES. Nuclear magnetic resonance imaging demonstrated several vague nodules in the area of conus medullaris and cauda equine, without lumbar or thoracic herniated discs. The serum carcinoembryonic antigen concentration was $191.20 \mathrm{ng} / \mathrm{mL}$. The conclusion following positron emission tomography-computed tomography was a right upper lung malignant tumor with mediastinal lymph node metastasis and cauda equina metastasis. Pathologic diagnosis was of primary adenocarcinoma of the lung by bronchoscopic biopsy. EML4-ALK fusion and EGFR mutations were absent, and thus the patient received chemotherapy. However, symptoms of intracranial hypertension arose 1 month later, and the patient died 3 months postadmission. Emerging CES may be a sign of metastasis of a malignant tumor, presenting an extremely challenging condition, especially for patients with lung cancer. Positron emission tomography-computed tomography is a fairly effective technique to make the diagnosis.
\end{abstract}

Keywords: cauda equine syndrome, leptomeningeal carcinomatosis, positron emission tomography-computed tomography, lung cancer

\section{Introduction}

Cauda equina syndrome (CES) is a neurological condition caused by compression of the cauda equine, and patients present with lower back pain, bilateral sciatica, saddle sensory disturbances, bladder and bowel dysfunction, and loss of sensory and motor function in the lower extremities. ${ }^{1}$ Common pathologies of CES include lumbar herniated disc, tumor, and infection. ${ }^{2}$ Leptomeningeal carcinomatosis arises from multifocal seeding of the leptomeninges by malignant cells, and presents in $1 \%-8 \%$ of patients with solid tumors, the majority of which are lung and breast cancers. ${ }^{3}$ Leptomeningeal carcinomatosis is a serious complication, with a median survival of 1.3 months without appropriate therapy. ${ }^{4}$ It is also unusual to present with leptomeningeal carcinomatosis without brain metastases.

Here, we demonstrate a case of CES as the primary symptom of leptomeningeal metastases from non-small cell lung cancer (NSCLC) without brain metastases.

\section{Case report}

A 59-year-old male suffered progressive sensory dysfunction in his lower extremities, arising 1 month prior to assessment, which was followed by urinary dysfunction and lower extremity motor dysfunction. He was clinically diagnosed with CES. Nuclear 
magnetic resonance image demonstrated several vague nodules in the area of conus medullaris and cauda equine, without evidence of herniation of the lumbar or thoracic discs (Figure 1A). The physicians came across a mass in the right upper lobe by thoracic computer tomography. The serum carcinoembryonic antigen concentration was $191.20 \mathrm{ng} / \mathrm{mL}$, which is 40 times the normal level.

The patient was then transferred to our hospital. Considering several tumor markers were abnormally elevated, we carried out positron emission tomography-computed tomography (PET/CT) immediately. PET images demonstrated an annular lesion with abnormal [18F]-fluorodeoxyglucose (FDG) accumulation in the right upper lobe, with a diameter of $3.2 \mathrm{~cm}$ and a maximum standardized uptake value $\left(\mathrm{SUV}_{\max }\right)$ of $16.9(\mathrm{kBq} / \mathrm{mL}) / \mathrm{MBq} / \mathrm{kg}$. Moreover, there were several nodules with enhanced FDG accumulation in the right lateral trachea, anterior to the carina and hilum, with the largest reaching $2.1 \mathrm{~cm}$ in size with an $\mathrm{SUV}_{\text {max }}$ of $21.0(\mathrm{kBq} / \mathrm{mL}) /$ $\mathrm{MBq} / \mathrm{kg}$ (Figure 1B and C). CT images showed the presence

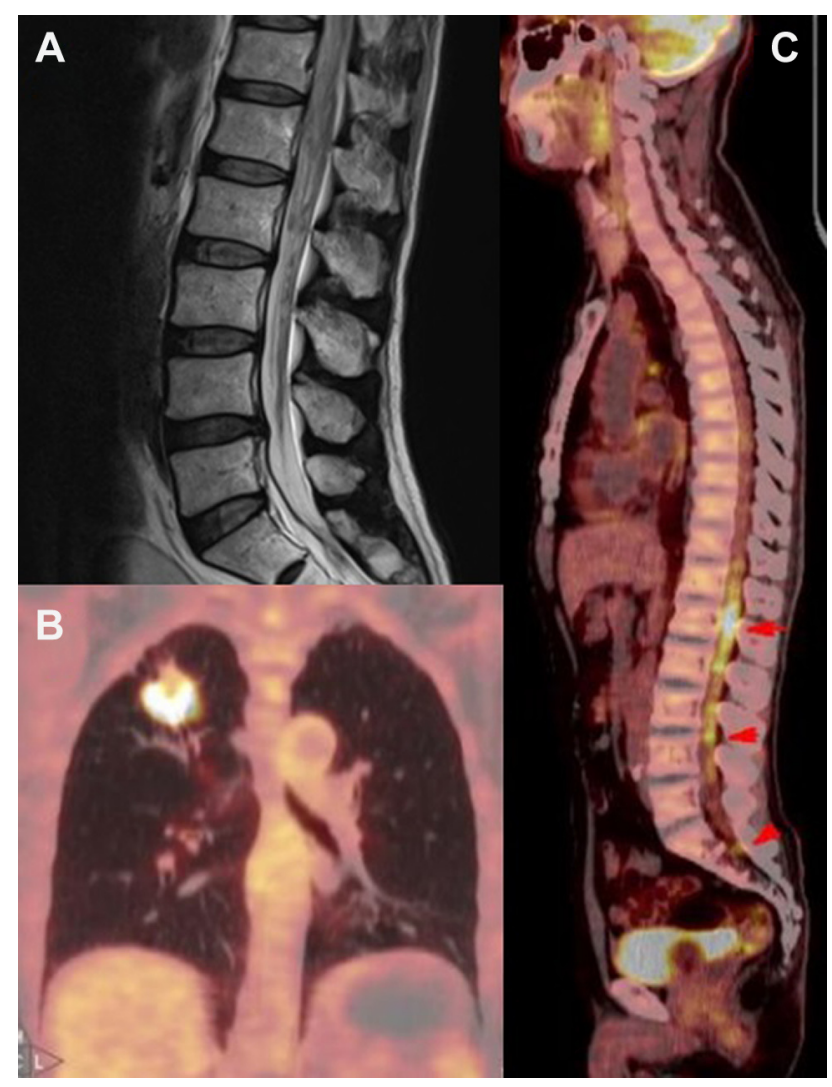

Figure I MRI and PET images.

Notes: (A) MRI scan displaying several vague nodules in the area of conus medullaris and cauda equine. (B) PET image displaying an annular lesion with abnormal FDG accumulation in the right upper lobe. (C) PET image displaying several nodules with increased FDG accumulation in the lumbosacral spinal cord.

Abbreviations: MRI, magnetic resonance imaging; PET, positron emission tomography; FDG, [I8F]-fluorodeoxyglucose. of a mass with lobulated/spiculated borders in the right upper lobe. Furthermore, we found several nodules with increased FDG accumulation in the lumbosacral spinal cord, without lumbar vertebral destruction, whose $\mathrm{SUV}_{\max }$ was $9.4(\mathrm{kBq} / \mathrm{mL}) / \mathrm{MBq} / \mathrm{kg}$. We came to the diagnosis of a right upper lung malignant tumor with mediastinal lymph nodes metastasis and cauda equina metastasis.

The patient underwent a bronchoscopic biopsy of the peripheral lung lesions, and was diagnosed with primary adenocarcinoma of the lung. An amplification refractory mutation system was applied to test for the presence of EML4-ALK fusion and/or mutations in EGFR, which includes deletions within exon 19, the G719X mutation in exon 18, the S768I mutation in exon 20, and the L858R mutation in exon 21. None of these common mutations were detected.

As chemotherapy was advised, cisplatin and pemetrexed disodium were administered to the patient. However, his physiological status deteriorated 1 week following chemotherapy treatment, and the patient and family members refused sequential courses of chemotherapy. Symptoms of intracranial hypertension arose 1 month later, and the patient died 3 months following admission.

\section{Discussion}

Spinal cord or cauda equina compression is increasing in patients with malignant tumors because of prolonged survival. Metastatic tumors can be seen in extradural, intradural extramedullary, and intramedullary locations, with no survival difference observed among these localizations. ${ }^{5}$ Intradural parenchymal involvement, a rare complication, can arise in $1.65 \%$ of patients with primary lung cancer, which is mostly derived from hematogenous dissemination, including from arterial and vertebral venous plexus routes. ${ }^{6}$ Meningeal carcinomatosis can also be combined with intradural parenchymal involvement. Cauda equina compression by metastatic lung cancer affects men more than women. ${ }^{7}$

Although rare, these patients have a poor prognosis. It was reported that 10 out of 131 patients presenting neurological symptoms resulting from spinal metastases displayed compression of the conus medullaris or cauda equina. Most of these neurological symptoms originated from lung cancer (33\%). Only $17 \%$ of patients with lung cancer responded well to treatment, and only $2 \%$ survived over 1 year. ${ }^{8}$ Before the $1990 \mathrm{~s}$, patients with intradural parenchymal involvement because of primary lung cancer only survived an average of 110 days. $^{6}$ Patients with leptomeningeal metastases had a prognosis of 6 months survival with normal cerebrospinal fluid flow, and 4 months survival when displaying interrupted cerebrospinal 
fluid flow. ${ }^{9}$ Gwak et $\mathrm{al}^{10}$ reported that patients with leptomeningeal carcinomatosis from NSCLC could only survive for 3 months while undergoing intraventricular chemotherapy.

Gwak et al ${ }^{10}$ also pointed out that younger age, better Karnofsky performance score, controlled intracranial pressure, greater amount of intraventricular chemotherapy, concurrent systemic chemotherapy, and receptor tyrosine kinase inhibitor administration were favorable prognostic factors. Among all variables, a better Karnofsky performance score is the strongest prognostic factor (hazard ratio: 2.57). ${ }^{10}$ Irradiation and corticosteroids have also been shown to be useful for relieving leg and back pain. ${ }^{11}$ Gefitinib, a tyrosine kinase inhibitor, has been shown to be effective in the treatment of neurological symptoms. ${ }^{12}$ Surgical removal of the intradural extramedullary mass can relieve CES, especially when presenting with impaired sphincter function, even if it has not been shown to help to improve survival times. ${ }^{13}$

In a review of the relevant literature, we examined 13 studies of CES related to lung cancer. We list the details of these articles in Table 1.
All 13 studies reported details of patients suffering from lung cancer with metastatic tumors, or nodules in conus medullaris or cauda equine, and included clinical symptoms, tumor pathology, interventions, curative effect, and survival time. In all, we considered 57 patients whose pathologies were as follows: adenocarcinoma in 6 patients, squamous carcinoma in 2 patients, small-cell lung cancer in 9 patients, large cell neuroendocrine carcinoma in 1 patient, NSCLC in 13 patients, and unknown in 26 patients. Except for 2 studies by Leviov et $\mathrm{al}^{11}$ and Alicioglu et al, ${ }^{17}$ the other 11 studies reporting precise survival information showed a mean survival time of 4.08 months. Treatment for these patients included intrathecal chemotherapy, ${ }^{3,9,10}$ systemic chemotherapy, ${ }^{3,10,13,15}$ spinal irradiation, ${ }^{3,11,14,15}$ laminectomy, ${ }^{13,16-19}$ high doses of dexamethasone, ${ }^{11,14}$ and tyrosine kinase inhibitors. ${ }^{12}$ The 35 patients undergoing a single medical intervention, excluding tyrosine kinase inhibitor treatment, survived an average of 3.19 months, ${ }^{9,10,14,16,18}$ whereas the 5 patients who underwent tyrosine kinase inhibitor treatment or two or more

Table I Details of the articles on CES related to lung cancer

\begin{tabular}{|c|c|c|c|c|c|}
\hline Study & $\begin{array}{l}\text { Number } \\
\text { of patients }\end{array}$ & Pathology & Survival time & Treatment & $\begin{array}{l}\text { Symptoms } \\
\text { improvement }\end{array}$ \\
\hline Leviov et al'" & 7 & UN & $\begin{array}{l}10 \text { months in ambulant } \\
\text { patients, } 2 \text { months in non- } \\
\text { ambulant patients }\end{array}$ & $\begin{array}{l}\text { High dose of dexamethasone and } \\
\text { spinal irradiation }\end{array}$ & $\begin{array}{l}2 \text { of } 7 \text { patients } \\
\text { recovered }\end{array}$ \\
\hline $\begin{array}{l}\text { Chamberlain and } \\
\text { Kormanik }^{9}\end{array}$ & 3 & UN & I, 3, 8 months & Intrathecal chemotherapy & Partially responded \\
\hline Okamoto et $\mathrm{al}^{6}$ & 9 & $3 \mathrm{AC}, 6 \mathrm{SCLC}$ & Mean: II 6 days, $28-220$ days & - & - \\
\hline Ampil et $\mathrm{al}^{14}$ & 16 & UN & Mean: 3 months & $\begin{array}{l}\text { Corticosteroid therapy and } \\
\text { conventional megavoltage } \\
\text { radiotherapy }\end{array}$ & $\begin{array}{l}\text { Clinical manifestations } \\
\text { improved }\end{array}$ \\
\hline Sakai et al ${ }^{12}$ & I & $A C$ & $>8$ months & Gefitinib & $\begin{array}{l}\text { Recovered and was } \\
\text { able to work }\end{array}$ \\
\hline Kotil et al ${ }^{15}$ & I & $A C$ & $>12$ months & $\begin{array}{l}\text { Laminectomy, radiotherapy, and } \\
\text { chemotherapy }\end{array}$ & $\begin{array}{l}\text { Recovered } 12 \text { months } \\
\text { postoperation }\end{array}$ \\
\hline Walid et $\mathrm{al}^{3}$ & I & SCLC & $>10$ months & $\begin{array}{l}\text { Intrathecal chemotherapy, spinal } \\
\text { radiotherapy, and systemic } \\
\text { chemotherapy }\end{array}$ & $\begin{array}{l}\text { Improved after } \\
\text { systemic chemotherapy }\end{array}$ \\
\hline Löhr et al ${ }^{16}$ & 2 & I SC, I AC & I.5 and 8 months & $\begin{array}{l}\text { Interlaminar fenestration and } \\
\text { subtotal resection, hemilaminectomy } \\
\text { and total resection of tumor }\end{array}$ & $\begin{array}{l}\text { Pain relieved and } \\
\text { neurological function } \\
\text { improved }\end{array}$ \\
\hline Alicioglu and Saynak ${ }^{17}$ & I & SC & - & - & - \\
\hline Lin et $\mathrm{al}^{18}$ & I & SCLC & 3 months & Laminectomy & - \\
\hline Tsimpas et al $^{19}$ & I & LCNC & $>12$ months & $\begin{array}{l}\text { Laminectomy and local spinal } \\
\text { radiotherapy (20) }\end{array}$ & Back pain improved \\
\hline Xiong and Zhang ${ }^{13}$ & I & SCLC & 12 months & $\begin{array}{l}\text { Laminectomy, systemic } \\
\text { chemotherapy }\end{array}$ & $\begin{array}{l}\text { Pain and urination } \\
\text { function improved }\end{array}$ \\
\hline Gwak et al ${ }^{10}$ & 13 & NSCLC & $\begin{array}{l}\text { Mean: } 3 \text { months, } \\
0.5-21.5 \text { months }\end{array}$ & $\begin{array}{l}\text { Intraventricular chemotherapy, with } \\
\text { or without systemic chemotherapy }\end{array}$ & $\begin{array}{l}2 \text { of } 13 \text { patients } \\
\text { recovered }\end{array}$ \\
\hline
\end{tabular}

Note: '-' = No data.

Abbreviations: CES, cauda equine syndrome; UN, unknown; AC, adenocarcinoma; SC, squamous carcinoma; SCLC, small-cell lung cancer; NSCLC, non-small-cell lung cancer; LCNC, large-cell neuroendocrine carcinoma. 
interventions survived an average of 10.8 months. ${ }^{3,12,13,15,19}$ Chemotherapy is the basic therapy for these patients. However, tyrosine kinase inhibitor treatment is the most effective therapy, which should be the first choice for patients with EGFR mutations. Laminectomy and tumor excision can significantly relieve cauda equine compression, which when combined with radiotherapy or chemotherapy can prolong life expectancy but has no increased survival effect on its own. Radiotherapy is considered a low palliative intervention, which can be an adjuvant treatment especially for squamous cell carcinomas. Intrathecal chemotherapy can be used to treat subclinical leptomeningeal deposits and tumor cells in the cerebrospinal fluid. ${ }^{20}$

\section{Conclusion}

Emerging CES may be a sign of metastasis of a malignant tumor, presenting an extremely challenging condition, especially for patients with lung cancer. Oncologists should have familiarity with this disease, and the use of PET/CT is a fairly effective technique to make the diagnosis. Tyrosine kinase inhibitor treatment is the most effective therapy, and combined medical therapies can also prolong a patient's life, including chemotherapy, radiotherapy, and laminectomy.

\section{Consent for publication}

The patient provided written informed consent for this study. Written informed consent for publication of the clinical details and/or clinical images was obtained from the patient's family.

\section{Ethics approval}

The Ethics Committee of the Third Affiliated Hospital of Soochow University approved this study. The analysis was performed in accordance with the ethical standards of the hospital.

\section{Acknowledgments}

This study was supported by The National Natural Science Fund (81701584) and the Natural Science Foundation of Changzhou Municipal Government (CJ20140030).

\section{Author contributions}

YL collected the details of the reported patient and reviewed related articles. BW performed literature review and composed the manuscript. YQ was in-charge of the patient. DD prepared and generated the figure. MW revised the manuscript. XZ participated in sequence alignment and revised the manuscript. All authors contributed toward data analysis, drafting and critically revising the paper and agree to be accountable for all aspects of the work.

\section{Disclosure}

The authors report no conflicts of interest in this work.

\section{References}

1. Korse NS, Pijpers JA, vanZwetE, ElzevierHW, Vleggeert-Lankamp CLA. Cauda equina syndrome: presentation, outcome, and predictors with focus on micturition, defecation, and sexual dysfunction. Eur Spine J. 2017;26(3):894-904.

2. Fraser S, Roberts L, Murphy E. Cauda equina syndrome: a literature review of its definition and clinical presentation. Arch Phys Med Rehabil. 2009;90(11):1964-1968.

3. Walid MS, Ajjan M, Johnston KW, Robinson JS. Cauda equina syndrome - think of cancer. Perm J. 2008;12(2):48-51.

4. Seute T, Leffers P, ten Velde GP, Twijnstra A. Leptomeningeal metastases from small cell lung carcinoma. Cancer. 2005;104(8):1700-1705.

5. Mohme M, Mende KC, Kratzig T, et al. Impact of spinal cord compression from intradural and epidural spinal tumors on perioperative symptoms - implications for surgical decision making. Neurosurg Rev. 2017;40(3):377-387.

6. Okamoto H, Shinkai T, Matsuno Y, Saijo N. Intradural parenchymal involvement in the spinal subarachnoid space associated with primary lung cancer. Cancer. 1993;72(9):2583-2588.

7. Ampil FL, Mills GM, Burton GV. A retrospective study of metastatic lung cancer compression of the cauda equina. Chest. 2001;120(5): $1754-1755$.

8. Stark RJ, Henson RA, Evans SJ. Spinal metastases. A retrospective survey from a general hospital. Brain. 1982;105(Pt 1):189-213.

9. Chamberlain MC, Kormanik P. Carcinoma meningitis secondary to non-small cell lung cancer: combined modality therapy. Arch Neurol. 1998;55(4):506-512.

10. Gwak HS, Joo J, Kim S, et al. Analysis of treatment outcomes of intraventricular chemotherapy in 105 patients for leptomeningeal carcinomatosis from non-small-cell lung cancer. $J$ Thorac Oncol. 2013;8(5):599-605.

11. Leviov M, Dale J, Stein M, et al. The management of metastatic spinal cord compression: a radiotherapeutic success ceiling. Int J Radiat Oncol Biol Phys. 1993;27(2):231-234.

12. Sakai M, Ishikawa S, Ito $\mathrm{H}$, et al. Carcinomatous meningitis from non-small-cell lung cancer responding to gefitinib. Int J Clin Oncol. 2006;11(3):243-245.

13. Xiong J, Zhang P. Cauda equina syndrome caused by isolated spinal extramedullary-intradural cauda equina metastasis is the primary symptom of small cell lung cancer: a case report and review of the literature. Int J Clin Exp Med. 2015;8(6):10044-10050.

14. Ampil FL, Caldito G, Heldmann M. Palliation and survival in metastatic tumors compressing the cauda equina: a 19-year radiotherapeutic experience. J Palliat Med. 2003;6(1):33-36.

15. Kotil K, Kilinc BM, Bilge T. Spinal metastasis of occult lung carcinoma causing cauda equina syndrome. J Clin Neurosci. 2007;14(4):372-375.

16. Löhr M, Tzouras G, Kocher M, et al. Treatment strategies of spaceoccupying intradural metastases of the cauda equina of nonneurogenic origin. Acta Neurochir (Wien). 2009;151(3):207-215.

17. Alicioglu B, Saynak M. Spinal leptomeningeal metastasis in a patient with squamous cell lung cancer. Rev Port Pneumol. 2008;14(6):875-879.

18. Lin CL, Chang JL, Lo HC, Wu KA. Extramedullary-intradural spinal metastasis of small cell lung cancer causing cauda equina syndrome. Am J Med Sci. 2010;339(2):192-194.

19. Tsimpas A, Post NH, Moshel Y, Frempong-Boadu AK. Large cell neuroendocrine carcinoma of the lung metastatic to the cauda equina. Spine J. 2010;10(6):e1-e5.

20. Grossman SA, Krabak MJ. Leptomeningeal carcinomatosis. Cancer Treat Rev. 1999;25(2):103-119. 
OncoTargets and Therapy

\section{Publish your work in this journal}

OncoTargets and Therapy is an international, peer-reviewed, open access journal focusing on the pathological basis of all cancers, potential targets for therapy and treatment protocols employed to improve the management of cancer patients. The journal also focuses on the impact of management programs and new therapeutic agents and protocols on

patient perspectives such as quality of life, adherence and satisfaction. The manuscript management system is completely online and includes a very quick and fair peer-review system, which is all easy to use. Visit http://www.dovepress.com/testimonials.php to read real quotes from published authors.

Submit your manuscript here: http://www.dovepress.com/oncotargets-and-therapy-journal 